\title{
Öğretmen Adaylarının Bilişötesi (Üst Biliş) Öğrenme Stratejileri ile Akademik Öz Yeterlik İnançları Arasındaki İlişki ${ }^{1}$
}

\author{
The Relationship Between Pre-Service Teachers' \\ Metacognitive Learning Strategies and Academic Self-Efficacy
}

\author{
Nihal Tunca \\ Dumlupınar Üniversitesi, Türkiye \\ tuncanihal@gmail.com
}

\author{
Senar Alkın-Şahin \\ Dumlupınar Üniversitesi, Türkiye \\ senar35@gmail.com
}

\begin{abstract}
Özet
Bu araştırmada, öğretmen adaylarının bilişötesi öğrenme stratejileri ile akademik özyeterlik inançlar arasındaki ilişkinin belirlenmesi amaçlanmıştır. Ayrıca araşıtırmada, bilişötesi öğrenme stratejileri ve akademik özyeterlik inançlarının "cinsiyet, sınıf düzeyi, akademik başarı ve öğrenim görülen üniversite" değişkenlerine göre farklılaşıp farklılaşmadığı incelenmiştir. Tarama modelindeki araștırmanın çalışma grubunu, 2010-2011 eğitim-öğretim yılı Güz yarıylında Ankara Üniversitesi, Anadolu Üniversitesi ve Eskişehir Osmangazi Üniversitesi Eğitim Fakültesinde öğrenim gören toplam 794 öğretmen adayı oluşturmaktadır. Araştırmanın verilerinin toplanmasında "Bilişötesi Öğrenme Stratejileri Ölçeği" ve "Akademik Özyeterlik Ölçeği" kullanılmıştır. Verilerin çözümlenmesinde, Pearson Momentler Çarpımı Korelasyon Katsayısı, $\mathrm{t}$ testi ve ANOVA ve Kruskall Wallis $\mathrm{H}$ testi kullanılmıştır. Araştırmadan elde edilen bulgular, öğretmen adaylarının bilişötesi öğrenme stratejileri ile akademik özyeterlik inançları arasında anlamlı ilişkiler olduğunu; bilişötesi öğrenme stratejilerinin cinsiyete akademik başarıya ve öğrenim görülen üniversiteye göre farklılaştı̆ı̆ıı; akademik özyeterlik inançlarının ise sınıf düzeyine, akademik başarıya ve öğrenim görülen üniversiteye göre farklılaştığını ortaya koymaktadır.
\end{abstract}

Anahtar Sözcükler: Bilişötesi (üst biliş) öğrenme stratejileri; Akademik özyeterlik inancl; Özyeterlik inancı.

\begin{abstract}
The purpose of the present study is to determine whether there is a relationship between the preservice teachers' metacognitive learning strategies and academic self-efficacy. Moreover, the study also looks at whether the metacognitive learning strategies and academic self-efficacy varies depending on the variables such as gender, the classroom level, achievement and university. The study group of this research employing a survey model consists of 794 pre-service teachers of all the departments of the Education Faculty of Ankara University, Anadolu University and Osmangazi University. "Metacognitive Learning Strategies Scale" and "Academic Self-Efficacy Scale" are used were data collection instruments of the study. Pearson Moments Product Correlation Coefficient, $t$ test, ANOVA and Kruskall Wallis $\mathrm{H}$ test were used in the analysis of the data. The findings of the study revealed that there are significant relations between the sub-dimensions of the metacognitive learning strategies and academic self-efficacy; pre-service teacher's metacognitive learning strategies differ significantly in terms of gender, achievement and university; academic self-efficacy differ significantly in terms of the classroom level, achievement and university.
\end{abstract}

\footnotetext{
${ }^{1}$ Bu makale, 6-9 Temmuz 2010 tarihleri arasında, Hong Kong'da düzenlenen 17. International Conference on Learning'de sunulan bildirinin geliştirilmiş halidir.
} 
Keywords: Metacognitive learning strategies and academic self-efficacy; Self-efficacy.

\section{Giriş}

Bireylerin yaşamları boyunca karşılaştıkları her türlü sorunu çözebilmeleri için öncelikle bu sorunla başa çıkabilecekleri konusunda kendilerine güvenmeleri, çözüm yollarını planlamaları, çözüme ilişkin planı uygularken kendi zihinsel süreçlerinin farkında olmaları, zihinsel süreçlerini izlemelerideğerlendirmeleri gerekmektedir. Bu bağlamda bireylerin karşılaştıkları sorunları çözebilmeleri için sahip olmaları gereken özelliklerden biri özyeterliktir. Özyeterlik, bireyin bir problemi çözmek ya da zor olan bir görevi başarıyla yerine getirmek amacıyla gerekli olan etkinlikleri (bilgilerini, becerilerini vb.) organize etme, uygulama ve uygulamalarını kontrol etme yeteneğine olan güveni ya da inancı olarak tanımlanmaktadır (Bandura, 1995; Eccles ve Wigfield, 2002). Alanyazın incelendiğinde bireylerin özyeterliklerini değerlendirmek amacıyla yapılan çalışmaların çoğunlukla matematik özyeterliği, fen bilgisi özyeterliği (Akbaş ve Çelikkaleli, 2006; Hazır-Bıkmaz, 2004), sosyal özyeterlik (Çubukçu ve Girmen, 2007) gibi farklı alanlarda yapılmış olduğu görülmektedir. Bu alanlar dışında eğitim araştırmacılarının özyeterlik ile ilgili yaptıkları çalışmalar sonucunda akademik yaşantıların her düzeyinde etkili olduğu belirlenen "akademik özyeterlik" kavramı ortaya atılmıştır (Bandura 1997; Pajares 1996). Akademik özyeterlik kavramı, öğrencinin akademik bir işi başarıyla tamamlayabilmesine ilişkin inancı olarak açıklanmıştır (Zimmerman 1995 Akt. Ekici, 2005). Yapılan çalışmalar sonucu, akademik özyeterlik inançları yüksek olan bireylerin, kendilerine daha yüksek hedefler oluşturdukları, verdikleri kararlarda tutarlı oldukları (Pajares, 1996; Yılmaz, Gürçay ve Ekici, 2007) yeni ve zor görevlerle daha kolay başa çıktıkları ve çaba harcamaya istekli oldukları (Jerusalem, 2002, Akt. Yılmaz, Gürçay ve Ekici, 2007), olumsuzluklarla karşılaştıklarında ısrarlı ve sabırlı oldukları (Aşkar ve Umay, 2001) ve problem çözme stratejileri geliştirdikleri (Schunk ve Pajares, 2001) tespit edilmiştir.

Bireylerin karşılaştıkları sorunları çözebilmeleri için sahip olmaları gereken diğer bir özellik ise üstbilişsel (bilişötesi) becerilerini kullanma yeterliliğidir. Üstbiliş, genel olarak bireyin kendi biliş sistemi, yapısı, çalışması hakkındaki bilgisidir. Üstbiliş kavramı ilk olarak Flavell (1985) tarafından kullanılmıştır. Flavell (1985), üstbilişi, "bilişsel fenomen hakkındaki bilgi ve biliş"; "kişinin kendi bilişsel süreçleri hakkındaki bilgisi ve bu bilginin bilişsel süreçleri kontrol etmek için kullanılması" olarak tanımlamıştır (Akt. Namlu, 2004). Welton ve Mallan (1999) ise üstbiliş kavramını, öğrencilerin kendi düşünme biçimleri üzerinde düşünmeleri ve düşünme süreçlerini denetleyebilmeleri olarak tanımlamıştır (Akt. Candan, 2005). Oxford (1990)'a göre, üstbiliş öğrenme stratejileri, öğrenmeyi merkeze alma stratejisi, planlama stratejisi ve değerlendirme stratejisi olmak üzere üç grup stratejiyi kapsamaktadır. Üstbiliş öğrenme stratejileri; öğrencilerin kendi bilişlerini kontrol etmelerine; yani merkezde toplama, sıraya dizme, planlama ve değerlendirme gibi işlevleri kullanarak öğrenme sürecini düzeltmelerine olanak sağlayan stratejilerdir (Hismanoğlu, 2000). Birey yeni bir problemle karşılaştığında, yukarıda sözü edilen üst biliş stratejileri, başarıı bir sonuca ulaşmada önemli rol oynamaktadır. Bu stratejiler yoluyla birey başarıı olup olamayacağını değerlendirir, görevi hangi adımlarla tamamlayacağına karar verir, işlemlerinin nasıl ilerlediğine dikkat eder ve o sırada edindiği tecrübeleri sonraki işlemlere transfer eder (Gourgey, 1998, Akt. Özsoy, 2008). Bireyde üstbiliş ile ortaya çıkması beklenen beceriler, kişinin kendisinin ve öğrenme yollarının farkında olması, bilinçli davranma, kendini kontrol, planlama, nasıl öğrendiğini izleme, kendini düzenleme, kendini değerlendirmedir (Doğanay, 1997). Yapılan araştırmalara genel olarak bakıldığında üstbilişsel becerilerin başarıyı (Çakıroglu, 2007; Özsoy, 2008) ve motivasyonu artırdığı (Demir-Gülşen, 2000), derse ilişkin tutumları olumlu yönde geliştirdiği (Küçük-Özcan, 2000; Gelen, 2004) kendini kontrol becerilerini geliştirdiği, bilgiyi elde etme yolunu geliştirdiği ve bilgiyi kullanmayı sağladığı (Ciardiello, 1998, Akt. Schoeffler, 2012) ve problem çözme becerilerini geliştirdiği (Howard, McGee, Shia ve Namsoo, 2000) görülmektedir.

Karşılaşılan problemlerin çözümünde bireyin kendine güvenmesi ve başarabileceğine inanması, problemi çözerken zorluklarla baş etmesi, probleme olası çözüm yolları ararken düşünme süreçlerini sürekli kontrol ederek değerlendirmesi dikkate alındığında sözü edilen akademik özyeterlik inancı ile üstbiliş kavramları arasında bir ilişki olması beklenmektedir. Alanyazın incelendiğinde özyeterlik inancı ile üstbiliş stratejileri arasındaki ilişkiyi inceleyen çok az çalışmaya rastlanmıştır. Özyeterlik inancı ile başarı arasındaki ilişkiyi açıklamayı amaçlayan çalışmalar (Kanfer ve Ackerman, 1989 Akt. LindsayColeen, 2010; Clause, Delbridge, Schmidt, Chan ve Jennings, 2001; Schunk ve Pajares, 2001; LindsayColeen, 2010) bu süreçte özyeterlik inancının üstbiliş stratejileriyle de ilişkili olduğunu ortaya 
koymuşlardır. Özyeterliği yüksek olan bireylerin verilen bir problemi çözerken öncelikle plan yaptığı, planı uygularken kendi zihinsel süreçlerini izlediği-değerlendirdiği yani üstbiliş stratejilerini kullandıkları ve sabırla, çaba göstererek başarıya ulaştıklarını belirtmişlerdir. Örneğin, Clause, Delbridge, Schmidt, Chan ve Jennings (2001), bir işyerine başvuruda bulunan bireylerin üstbilişsel stratejileri kullanımı ile özyeterlik inançları arasındaki ilişkiyi incelemişler ve yüksek özyeterliğe sahip katılımcıların daha çok üstbilişsel stratejileri kullandıkları sonucuna ulaşmışlardır. Aynı çalışmada araştırmacılar özyeterlik, üstbiliş stratejileri ve başarı arasındaki ilişkiyi modellemiş ve elde ettikleri modelde özyeterlik ve başarı arasındaki ilişkiye üstbilişsel becerilerin aracılık ettiği sonucuna ulaşmışlardır.

Toplumların, gereksinim duydukları insan gücünü yetiştirerek, yaşam kalitesini yükseltecek olan öğretmenlerin, karşılaştıkları sorunlara olası çözüm yolları üretebilmek için kendi düşünme süreçlerini sürekli kontrol ederek ve değerlendirerek stratejiler geliştiren, bu stratejileri uygulama konusunda kendilerine güvenen ve bu süreçte sabırlı olan bireyler olmaları gerekmektedir. Diğer bir deyişle, öğretmenlerin başarıya ulaşmaları için akademik özyeterlik inancına sahip olmaları ve aynı zamanda üstbiliş stratejilerini işe koşmaları beklenmektedir. Özyeterlikle ilgili alanyazın incelendiğinde yapılan çalışmaların daha çok öğretmenlerin/öğretmen adaylarıın farklı alanlardaki (akademik, biyoloji, fen vb) özyeterlik inançlarının farklı değişkenlere göre incelenmesine yönelik olduğu görülmektedir (Çubukçu ve Girmen, 2007; Ekici, 2008; Üstün ve Tekin, 2009; Saracaloğlu, Karasakaloğlu ve EvinGencel, 2010; Akay ve Boz, 2011; Özsüer, İnal, Uyanık ve Ergün, 2011; Doğan, Beyaztaş, Koçak, 2012). Üstbilişle ilgili alanyazın incelendiğinde ise yapılan çalışmaların daha çok öğretmenlerin/öğretmen adaylarının üstbiliş stratejilerinin farklı değişkenlere göre incelenmesine yönelik çalışmalar (Memnun ve Akkaya, 2009; Özsoy, Çakıroğlu ve Kuruyer, 2010; Aydın ve Coşkun, 2011; Özsoy ve Günindi, 2011) olduğu görülmektedir. Ancak başarıya giden yolda aynı anda işe koşulması önerilen üstbiliş stratejileri ile akademik özyeterlik inançları arasındaki ilişkiyi inceleyen çalışmaya ulaşılamamıştır. Bu gereksinimden hareketle bu çalışmada öğretmen adaylarının üstbiliş stratejileri ile akademik özyeterlik inançları arasındaki ilişkinin belirlenmesi; üstbiliş stratejileri ile akademik özyeterlik inançlarının cinsiyete, sınıf düzeyine, akademik başarıya ve öğrenim gördükleri üniversiteye göre farklılaşıp farkılış̧madığının belirlenmesi amaçlanmaktadır. Bu genel amaca ulaşmak için aşağıdaki sorulara yanıt aranmıştır:

1. Öğretmen adaylarının üstbiliş öğrenme stratejileri ile akademik öz yeterlik inançları arasında ilişki var mıdır?

2. Öğretmen adaylarının üstbiliş öğrenme stratejileri ve akademik özyeterlik inançları cinsiyetlerine, öğrenim gördükleri sınıfa, üniversitelerine ve akademik başarılarına göre fark göstermekte midir?

\section{Yöntem}

\section{Araştırmanın Modeli}

Öğretmen adaylarının üstbiliş öğrenme stratejileri ile akademik öz yeterlik inançları arasındaki ilişkinin belirlenmesine yönelik olan bu araştırma tarama modelinde olup, çalışmada varolan durum yansıtıımaya çalışılmıştır.

\section{Araştırmanın Çalışma Grubu}

Araştırmanın çalışma grubunu Anadolu Üniversitesi Eğitim Fakültesi, Ankara Üniversitesi Eğitim Bilimleri Fakültesi ve Osmangazi Üniversitesi Eğitim Fakültesi'nde öğrenim gören toplam 794 öğretmen adayından oluşmaktadır. Araştırmaya katılan öğretmen adaylarından \% 61.8'i kız, \% 38.2'si erkektir. Öğretmen adaylarının \%56'sı 1. sınıfta, \% 44'ü 4. sınıfta; \% 34.3'ü Anadolu Üniversitesi'nde, \% 30.7'sı Ankara Üniversitesi'nde ve \% $35^{\prime} \mathrm{i}$ ise Osmangazi Üniversitesi'nde öğrenim görmektedir. Öğretmen adaylarının \% 0.8'i 0 ile 0.99, \% 6.7'si 1.00 ile 1.99, \%56'sı 2.00-2.99, \% 36.5'i 3.00-4.00 arasında ortalamaya sahiptir.

\section{Veri Toplama Araçları}


Araştırmada veri toplama araçları olarak, Jerusalem ve Schwarzer (1981) tarafından geliştirilen ve Yılmaz, Gürçay ve Ekici (2007) tarafından uyarlanan "Akademik Özyeterlik Ölçeği" ile Namlu (2004) tarafından geliştirilen "Bilişötesi Öğrenme Stratejileri Ölçeği" kullanılmıştır. Veri toplama araçlarının kullanımı için adı geçen yazarlardan izin alınmışır.

Bilişötesi Öğrenme Stratejileri Ölçeği'nde 21 madde yer almaktadır ve 4 boyuttan oluşan formun a güvenirlik katsayıSı .81 olarak bulunmuştur. Ölçeğin boyutlarının güvenirlik katsayıları ise şöyledir: Planlama Stratejileri boyutu $a=.69$, Örgütleme Stratejileri boyutu $a=.74$, Denetleme Stratejileri boyutu $a=.67$, Değerlendirme Stratejileri boyutu $a=.49$. ölçeğin açıkladığı toplam varyans $.45^{\prime}$ tir (Namlu, 2004).

Akademik Özyeterlik Ölçeği'nin Türkçe'ye uyarlanmış formunda 7 madde yer almaktadır. Ölçek tek faktörden oluşmaktadır ve a güvenirlik katsayısı .79 olarak bulunmuştur (Yılmaz, Gürçay ve Ekici, 2007).

\section{Verilerin Analizi}

Verilerin analizinde korelasyon, $\mathrm{t}$ testi, tek yönlü varyans analizi (ANOVA) ve Kruskall Wallis $\mathrm{H}$ Testi analizleri kullanılımışır. Öğretmen adaylarının;

- Akademik Özyeterlik Ölçeği ile Bilişötesi Öğrenme Stratejileri Ölçeği puanları arasındaki ilişkiler Pearson Momentler Çarpımı Korelasyon Katsayısı (Pearson r) ile incelenmiştir.

- "Cinsiyet" ve "sınıf" değişkenlerine göre Akademik Özyeterlik Ölçeği ve Bilişötesi Öğrenme Stratejileri Ölçeği toplam puan ve alt ölçek puanlarına ilişkin karşılaştırmalar $t$ testi ile yapılmışııı.

- Üniversite" değişkenine göre Akademik Özyeterlik Ölçeği ve Bilişötesi Öğrenme Stratejileri Ölçeği toplam puan ve alt ölçek puanlarına ilişkin karşılaştırmalar tek yönlü varyans analizi (ANOVA) ile yapılmıştır.

- "Akademik başarı" değişkenine göre Akademik Özyeterlik Ölçeği ve Bilişötesi Öğrenme Stratejileri Ölçeği toplam puan ve alt ölçek puanlarına ilişkin karşılaştırmalar tek yönlü varyans analizinin (ANOVA) parametrik olmayan karşılığı Kruskall Wallis H Testi ile yapılmıştır.

\section{Bulgular}

Bu bölümde, araştırma amaçları doğrultusunda elde edilen bulgulara yer verilmiştir.

\section{Öğretmen Adaylarının Bilişötesi Öğrenme Stratejileri İle Akademik Özyeterlik İnançları Arasında İlişki}

Araştırmada, Pearson korelasyon katsayısı (r); Akademik Özyeterlik İnançları Ölçeği toplam puanı ile bilişötesi öğrenme stratejileri toplam puanı arasında .36; ayrıca Akademik Özyeterlik İnançları Ölçeği toplam puanı ile biliş ötesi stratejilerinin ölçeğinin planlama alt boyutu puanı arasında .22; örgütleme alt boyutu puanı arasında .27; Denetleme alt boyutu puanı arasında .36; Değerlendirme alt boyutu puanı arasında .11 olarak hesaplanmıştır. Hesaplanan korelasyon katsayıları incelendiğinde, Bilişötesi Öğrenme Stratejileri ile Akademik Özyeterlik Ölçeklerinin toplam puanları arasındaki tüm ilişkinin orta düzeyde, pozitif ve anlamlı olduğu görülmektedir. Akademik Özyeterlik Ölçeği toplam puanı ile Bilişötesi Öğrenme Stratejileri alt boyutları puanları arasındaki ilişkilerin ise düşük ve orta düzeyde, pozitif ve anlamlı olduğu görülmektedir. Bu ilişkiler, biliş ötesi öğrenme stratejilerini kullanan öğretmen adaylarının akademik özyeterlik inançlarının daha yüksek olduğu biçiminde yorumlanabilir.

\section{Öğretmen Adaylarının Akademik Özyeterlik İnançlarının ve Bilişötesi Öğrenme Stratejilerinin Bazı Değişkenlere Göre Anlamlı Olarak Farklılaşma Durumu}

Cinsiyete göre, öğretmen adaylarının Bilişötesi Öğrenme Stratejileri Ölçeğinin Değerlendirme $[\mathrm{t}(791)=0.68 ; \mathrm{p}>.05]$ boyutuna ilişkin aldıkları puanlar dışında Bilişötesi Öğrenme Stratejileri Ölçeğinden aldıkları toplam puanlar $[\mathrm{t}(791)=3.70 ; \mathrm{p}<.05]$ ile Planlama [t(791)=3.22; $\mathrm{p}<.05]$, 
Örgütleme $[\mathrm{t}(791)=3.79 ; \mathrm{p}<.05]$, Denetleme $[\mathrm{t}(791)=2.40 ; \mathrm{p}<.05]$ boyutlarından aldıkları puanlara ilişkin farklıı̆̆ın anlamlı olduğu belirlenmiştir. Gruplara ait ortalamalar dikkate alındığında Bilişötesi Öğrenme Stratejileri Ölçeğinden alınan toplam puanda ve bilişötesi öğrenme stratejilerinin Planlama, Örgütleme, Denetleme boyutlarından alınan puanlarda da kadın öğretmen adaylarının ortalamalarının erkek öğretmen adaylarının daha yüksek olduğu belirlenmiştir. Araştırmaya katılan öğretmen adaylarının Akademik Özyeterlik İnançları Ölçeği puanlarında $[\mathrm{t}(791)=1.42 ; \mathrm{p}>.05]$ ise cinsiyete göre anlamlı bir farkııı̆ın olmadığı belirlenmiştir. Bu bulgu kadın ve erkek öğretmen adaylarının akademik özyeterlik inançlarının benzer düzeyde olduğunu göstermektedir.

Sınıf düzeyine göre, öğretmen adaylarının Bilişötesi Öğrenme Stratejileri Ölçeğinden aldıkları toplam puana $[\mathrm{t}(791)=1.63 ; \mathrm{p}>.05]$ ve alt boyutlarından (Planlama: $[\mathrm{t}(791)=1.86 ; \mathrm{p}>.05]$, Örgütleme: $[\mathrm{t}(791)=0.06 ; \mathrm{p}>.05]$, Denetleme: $[\mathrm{t}(791)=1.32 ; \mathrm{p}>.05]$, Değerlendirme: $[\mathrm{t}(791)=1.97 ; \mathrm{p}>.05])$ aldıkları puanlara ilişkin farklıı̆ın anlamlı olmadığı belirlenmiştir. Bu bulgu bilişötesi öğrenme stratejileri açısından birinci sınıf ve dördüncü sınıf öğretmen adaylarının benzer düzeyde olduklarını göstermektedir. Buna karşın sınıf düzeyine göre öğretmen adaylarının Akademik Özyeterlik İnançları Ölçeğinden aldıkları puanlara [t(791)=3.91; $\mathrm{p}<.05]$ ilişkin farklıı̆ın anlamlı olduğu belirlenmiştir. Gruplara ait ortalamalar dikkate alındığında dördüncü sınıf öğretmen adaylarının ortalamalarının birinci sınıflardan yüksek olduğu belirlenmiştir.

Akademik başarılarına göre, öğretmen adaylarının bilişötesi öğrenme stratejilerinin Denetleme $\left[\chi^{2}\right.$ $(3)=7.23 ; p>.05]$ ve Değerlendirme $\left[\chi^{2}(3)=3.37 ; p>.05\right]$ boyutlarından aldıkları puanların anlamlı olarak farklılaşmadığı belirlenmiştir. Buna karşın öğretmen adaylarının hem Biliş Ötesi Öğrenme Stratejileri Ölçeğinden aldıkları toplam puanlara $\left[\chi^{2}(3)=20.91 ; p<.05\right]$ ve bu ölçeğin Planlama $\left[\chi^{2}\right.$ $(3)=21.53 ; p<.05]$, Örgütleme $\left[\chi^{2}(3)=21.55 ; p<.05\right]$ boyutlarından ve Akademik Özyeterlik İnançları Ölçeğinden $\left[\chi^{2}(3)=35.43 ; p<.05\right]$ aldıkları puanlara ilişkin farklılığın anlamlı olduğu belirlenmiştir. Farkın kaynağını bulmak üzere Mann Whitney U Testi ile ikili karşılaştırmalar yapıldığında; hem bilişötesi öğrenme stratejileri toplam puanları hem de Planlama ve Örgütleme boyutları puanları açısından farkın, 3.00-4.00 akademik ortalamaya sahip öğretmen adayları ile 1-1,99 ve 2.00-2,99 ortalamalara sahip öğretmen adayları arasında olduğu bulunmuştur. Bilişötesi öğrenme stratejileri toplam puanları ile Planlama ve Örgütleme boyutlarından alınan puanlar açısından sıra ortalamaları dikkate alındığında, 3.00 - 4.00 akademik ortalamaya sahip öğretmen adaylarının $2.00-2.99$ ve 1.00 ile 1.99 akademik ortalamaya sahip öğretmen adaylarından bilişötesi öğrenme stratejilerini, Planlama ve Örgütleme stratejilerini daha fazla kullandıkları anlaşılmaktadır. Akademik Özyeterlik İnançları Ölçeğindeki farklılık ise 1.00-1,99 akademik ortalamaya sahip öğretmen adayları ile 2.00-2.99 ve 3.004.00 akademik ortalamaya sahip öğretmen adayları; 2.00-2.99 akademik ortalamaya sahip öğretmen adayları ile 3.00-4.00 akademik ortalamaya sahip öğretmen adayları arasındadır. Sıra ortalamaları dikkate alındığında, 2.00-2.99 akademik ortalama sahip öğretmen adaylarının, 1.00-1.99 akademik ortalamaya sahip öğretmen adaylarından; 3.00-4.00 akademik ortalamaya sahip öğretmen adaylarının hem 1.00-1.99 hem de 2.00-2.99 akademik ortalamaya sahip öğretmen adaylarından Akademik Özyeterlik İnançlarının daha yüksek olduğu belirlenmiştir.

Öğrenim gördükleri üniversiteye göre, öğretmen adaylarının Bilişötesi Öğrenme Stratejileri Ölçeğinin Planlama $[F(2)=1.14 ; p>.05]$, Örgütleme $[F(2)=0,82 ; p>.05]$ ve Değerlendirme $[F(2)=2,41 ; p>.05]$ boyutlarından aldıkları puanlar arasında anlamlı bir fark yokken; Bilişötesi Öğrenme Stratejileri Ölçeği toplam puanları $[F(2)=3,18 ; p<.05]$ ve Denetleme $[F(2)=5.17 ; p<.05]$ boyutundan aldıkları puanlar arasında anlamlı bir fark bulunmuştur. Öğretmen adaylarının Akademik Özyeterlik Ölçeği toplam puanları $[F(2)=3,23 ; p<.05]$ da öğrenim gördükleri üniversiteye göre farklılaşmaktadır. Bilişötesi Öğrenme Stratejileri toplam puanları ve denetleme boyutu puanları arasındaki farkların kaynağını bulmak üzere yapılan Dunnett testi sonuçlarına göre, Anadolu Üniversitesi'nde öğrenim gören öğretmen adaylarının bilişötesi öğrenme stratejileri puanlarının Osmangazi Üniversitesi'nde öğrenim görenlerden yüksek olduğu belirlenmiştir. Akademik Özyeterlik Ölçeği toplam puanları arasındaki farkların kaynağını bulmak üzere yapılan Scheffe testi sonuçlarına göre ise Anadolu Üniversitesi'nde öğrenim gören öğretmen adaylarının akademik öz yeterlik puanlarının Osmangazi Üniversitesi'nde öğrenim görenlerden yüksek olduğu belirlenmiştir. 


\section{Sonuç, Tartışma ve Öneriler}

Bu araştırmada, öğretmen adaylarının üstbiliş öğrenme stratejileri ile akademik özyeterlik inançları arasındaki ilişkinin belirlenmesi; ayrıca, üstbiliş öğrenme stratejilerinin ve akademik özyeterlik inançlarının bazı değişkenlere göre farkılışıp farklılaşmadığının belirlenmesi amaçlanmıştır.

Araştırmada, öğretmen adaylarının bilişötesi öğrenme stratejileri ile akademik özyeterlik inançları arasında orta düzeyde anlamlı bir ilişki bulunmuştur. Genel olarak, beklenenden daha düşük düzeyde olmakla birlikte, belirlenen ilişkinin anlamlı olması, bilişötesi öğrenme stratejileri ile akademik özyeterlik inançları arasındaki ilişkinin varlığına ilişkin bir kanıt sunmaktadır. Ancak kuramsal alanyazın dikkate alındığında (Kanfer and Ackerman, 1989, Akt. Lindsay-Coleen, 2010; Clause, Delbridge, Schmidt, Chan, and Jennings, 2001; Lindsay-Coleen, 2010) söz konusu iki değişkenin arasında daha güçlü bir ilişki olması beklenmektedir. Araştırmada her iki değişken arasında orta düzeyde bir ilişki olmasına karşın, belirlenen bu ilişki, akademik özyeterlik inançları yüksek olan öğretmen adaylarının biliş ötesi öğrenme stratejilerini daha çok kullandıklarını göstermektedir. Alanyazında doğrudan bilişötesi öğrenme stratejileri ile akademik özyeterlik inançları arasındaki ilişkiyi konu alan çalışmaya rastlanmamıştır. Ancak özyeterlik inancı ile bilişötesi öğrenme stratejilerini inceleyen çok az çalışma, bu araştırmadan elde edilen bulguyu destekler niteliktedir. Örneğin Landline ve Stewart (1998) üstbiliş, motivasyon, kontrol odağı ve özyeterlik arasındaki ilişkileri inceledikleri araştırmalarında, üst biliş ile özyeterlik arasında anlamlı bir ilişki olduğunu belirlemişlerdir. Coleen-Lindsay (2010) ise sınav kaygısı, üst biliş, özyeterlik ile hedef yönlendirmesi arasındaki ilişkileri incelediği çalışmasında, özyeterlik ile üst biliş arasında .88 düzeyinde anlamlı bir ilişki olduğunu belirlemiştir. Baykara (2011) ise yaptığı çalışmada, öğretmen adaylarının bilişötesi öğrenme stratejileri ile öğretmen yeterlik algılarını incelemiş ve öğretmen adaylarının öğretmenlik yeterlik algıları ile bilişötesi öğrenme stratejileri arasındaki ilişkiyi incelemiş iki değişken arasında anlamlı bir ilişki olduğu sonucuna ulaşmıştır.

Araştırmada öğretmen adaylarının Bilişötesi Öğrenme Stratejileri Ölçeğinin Değerlendirme boyutundan aldıkları puanlar arasında cinsiyete göre anlamlı farkılık yokken; Bilişötesi Öğrenme Stratejileri Ölçeği toplam puanları ile Planlama, Örgütleme ve denetleme boyutundan aldıkları puanlar arasında kadınların lehine anlamlı farklılıklar vardır. Alanyazın ilgili bulgu açısından incelendiğinde, yapılan pek çok çalışmanın sonucu (Memnun ve Akkaya, 2009; Özsoy, Çakıroğlu ve Kuruyer, 2010; Aydın ve Coşkun, 2011; Özsoy ve Günindi, 2011; Dilci ve Kaya, 2012) bu çalışmanın aksine cinsiyetin bilişötesi öğrenme stratejilerinin kullanımına etki etmediğini göstermektedir. Bu çalışmada, ilgili boyutlar açısından kadın öğretmen adaylarının ortalamalarının erkek öğretmen adaylarından daha yüksek olduğu yani kadın öğretmen adaylarının bilişötesi öğrenme stratejilerini erkek öğretmen adaylarına göre daha çok kullandıkları sonucuna ulaşııışıı. Alanyazında bu araştırma bulgusunu destekleyen çalışmalar da vardır. Örneğin Demir ve Özmen (2011), üniversite öğrencileri ile yürüttüğü çalışmalarında, kadın öğrencilerin erkek öğrencilere göre daha fazla bilişötesi öğrenme stratejilerini kullandığı sonucuna ulaşmışlardır. Baykara (2011) ise öğretmen adaylarının bilişötesi öğrenme stratejileri ile öğretmen yeterlik algılarını incelediği çalışmasında, kadın öğretmen adaylarının erkek öğretmen adaylarına göre "Örgütleme stratejilerini" daha fazla kullandıkları sonucuna ulaşmışlardır.

Araştırmada öğretmen adaylarının Akademik Özyeterlik İnançları Ölçeğinden aldıkları puanların cinsiyete göre anlamlı olarak farklılaşmadığı belirlenmiş̧ir. Araştırmaya katılan kadın ve erkek öğretmen adaylarının akademik özyeterlik inançları açısından benzer düzeyde oldukları söylenebilir. Akademik özyeterlik inançlarıyla ilgili alanyazında yapılan az sayıdaki çalışma incelendiğinde, araştırma bulgusunu destekleyen çalışmaların olduğu görülmektedir. Örneğin Can, Günhan-Cantürk ve Erdal'ın (2005), Oğuz'un (2012) ve Çuhadar, Gündüz, Tanyeri'nin (2013) yaptıkları çalışmalarda, öğretmen adaylarının akademik özyeterlik inançlarının cinsiyete göre farklılaşmadığı sonucuna ulaşmışlardır. Farklı alanlara ilişkin özyeterlik inançlarıyla ilgili alanyazın incelendiğinde de, araştırma bulgusunu destekleyen çalışmaların (Üredi ve Üredi, 2005; Çubukçu ve Girmen, 2007; Ekici, 2008; Üstün ve Tekin, 2009; Saracaloğlu, Karasakaloğlu ve Evin-Gencel, 2010; Akay ve Boz, 2011; Özsüer, İnal, Uyanık ve Ergün, 2011; Doğan, Beyaztaş, Koçak, 2012; Yasa ve Şahin, 2012) olduğu görülmektedir. Araştırma bulguları, bu çalışmada elde edilen bulgu ile genel olarak örtüşmekle birlikte, alanyazında akademik özyeterlik inançlarının cinsiyete göre farklılaştığı sonucuna ulaşan bir çalışmaya rastlanmıştır. Bu çalışma, Durdukoca (2010) tarafından sınıf öğretmeni adayları üzerinde yapılan bu çalışmada erkek 
öğretmen adaylarının akademik özyeterlik inançlarının kadın öğretmen adaylarına göre daha yüksek olduğu sonucuna ulaşılmıştır.

Araştırmada öğretmen adaylarının Bilişötesi Öğrenme Stratejileri Ölçeği ve alt boyutlarından aldıkları puanların sınıf düzeyine göre farklılaşmadığı belirlenmiştir. Bu bulgu bilişötesi öğrenme stratejileri açısından birinci sınıf ve dördüncü sınıfta öğrenim gören öğretmen adaylarının benzer düzeyde olduklarını göstermektedir. Alanyazın ilgili değişken açısından incelendiğinde, Özsoy, Çakıroğlu ve Kuruyer'in (2010), Demir ve Özmen'in (2011) ve Baykara'nın (2011) öğretmen adayları üzerinde yaptıkları çalışmalar, araştırma bulgusunu destekler niteliktedir. Ancak deneyimlerin, üst bilişin gelişimine ve bilişötesi öğrenme stratejilerinin kullanımına katkı sağladığı (Brown, 1987, Akt. Özsoy, 2008) dikkate alındığında, dördüncü sınıf öğretmen adaylarının birinci sınıflara göre bilişötesi öğrenme stratejilerini daha fazla kullanıyor olmaları beklenmektedir. Alanyazında bilişötesi öğrenme stratejileriyle ilgili bu kuramsal açıklamayı destekleyen ve araşı̧ıma bulgusuyla örtüşmeyen çalışmalar da vardır. Örneğin, Özsoy ve Günindi (2011) ile Memnun ve Akkaya'nın (2009) öğretmen adayları üzerinde yaptıkları çalışmalarında dördüncü sınıf öğrencilerinin daha alt sınıflara göre bilişötesi öğrenme stratejilerini daha fazla kullandıkları sonucuna ulaşmışlardır.

Araştırmada öğretmen adaylarının Akademik Özyeterlik İnançları Ölçeğinden aldıkları puanların sınıf düzeyine göre anlamlı farklılık gösterdiği belirlenmiştir. Araştırmada dördüncü sınıf öğretmen adaylarının birinci sınıf öğretmen adaylarına göre akademik özyeterlik inançlarının daha yüksek olduğu belirlenmiş̧ir. Bu sonuç beklenen yöndedir. Dördüncü sınıf öğrencilerinin birinci sınıf öğrencilerine göre akademik özyeterlik inançlarının yüksek olmasının nedenleri, alan bilgisi ve öğretmenlik meslek bilgisine ilişkin alınan derslerin daha fazla olması, alınacak derslere ilişkin ise öğretim üyelerinin ders işleme ve ölçme değerlendirme yöntemlerini tanımış olmaları ve ilk üç sınıfı başarıyla tamamlamış olmalarının yaratmış olduğu güven olabilir. Alanyazında akademik özyeterlikle ilgili yapılan çalışmalar incelendiğinde, Durdukoca (2010) ve Oğuz'un (2012) sınıf öğretmen adayları üzerinde yaptıkları çalışmaların sonuçlarının araştırma bulgusunu desteklediği görülmektedir. Farklı alanlara ilişkin özyeterlik inançlarıyla ilgili alanyazın incelendiğinde de, araştırma bulgusunu destekleyen çalışmaların (Can, Günhan-Cantürk ve Erdal, 2005; Üredi ve Üredi, 2005; Aydın ve Boz, 2010; Çalışkan, Selçuk ve Özcan, 2010) olduğu görülmektedir.

Araştırmada, öğretmen adaylarının, Bilişötesi Öğrenme Stratejileri ölçeğinden ve denetleme boyutundan aldıkları puanların öğrenim gördükleri üniversiteye göre anlamlı farklılık gösterdiği belirlenmiş̧ir. Araştırmada Anadolu Üniversitesi'nde öğrenim gören öğretmen adaylarının bilişötesi öğrenme stratejileri puanlarının Osmangazi Üniversitesi'nde öğrenim görenlerden daha yüksek olduğu belirlenmiştir. Bu farklılık, Anadolu Üniversitesi Eğitim Fakültesi'ne giriş puanlarının Osmangazi Üniversitesi Eğitim Fakültesi'ne giriş puanlarından daha yüksek olmasına bağlı olabilir. Bu farklıı̆ı̆n bir başka nedeni, Anadolu Üniversitesi Eğitim Fakültesi'nde öğrenim gören öğretmen adaylarının aldıkları derslerde bilişötesi öğrenme stratejilerinin kullanımına ilişkin farkındalıklarının artırımış olması olabilir.

Araştırmada, öğretmen adaylarının, Akademik Özyeterlik Ölçeğinden aldıkları puanların öğrenim gördükleri üniversiteye göre anlamlı farklılık gösterdiği belirlenmiştir. Araştırmada Anadolu Üniversitesi'nde öğrenim gören öğretmen adaylarının akademik özyeterlik inançlarının Osmangazi Üniversitesi'nde öğrenim görenlerden daha yüksek olduğu belirlenmiş̧ir. Bu farklılığın nedeni, bilişötesi öğrenme stratejilerinde olduğu gibi Anadolu Üniversitesi Eğitim Fakültesi'ne giriş puanlarının Osmangazi Üniversitesi Eğitim Fakültesi'ne giriş puanlarından daha yüksek olmasına bağlı olabilir. Anadolu üniversitesinde öğrenim gören öğretmen adaylarının üniversite sınavında daha başarılı olması onların kendilerine akademik olarak daha fazla güvenmelerini sağlamış olabilir.

Araştırmada bilişötesi öğrenme stratejileri ile akademik özyeterlik inancı arasında anlamlı ilişkilerin bulunması, öğretim kurumlarında bilişötesi öğrenme stratejilerinin öğretiminin akademik özyeterlik inancının artııımasına katkı sağlayacağına ilişkin ipucu sunmaktadır. Bu bağlamda öncelikle, öğretmen eğitimi programlarında bilişötesi öğrenme stratejilerine ilişkin dersler konularak ya da bilişötesi öğrenme stratejilerinin belirlenen dersler içinde dolaylı öğretimi sağlanarak öğrencilerde farkındalık kazandırımalıdır. Bunun yanında, bilişötesi öğrenme stratejileri ile akademik özyeterlik inancı arasındaki ilişkiye dair daha güçlü vurguların yapılabilmesi için daha büyük çalışma grupları üzerinde ve farklı öğretim kurumlarında araştırmalar yapılabilir. Bu konuda daha genellenebilir sonuçlara ulaşıması, 
yalnızca eğitim fakültelerinde uygulanan öğretim programlarının yapılandııımasına değil diğer öğretim kurumlarının programlarının da yapılandııımasına katkı sağlayacaktır.

\section{Kaynakça}

Akay, H. ve Boz, N. (2001). Sınıf öğretmeni adaylarının matematiğe yönelik tutumları, matematiğe karşı öz-yeterlik algıları ve öğretmen öz-yeterlik inançları arasındaki ilişkilerin incelenmesi. Türk Eğitim Bilimleri Dergisi, 9(2), 281-312.

Akbaş, A. ve Çelikkaleli, Ö. (2006). Sınıf Öğretmeni Adaylarının Fen Öğretimi Öz-Yeterlik İnançlarının Cinsiyet, Öğrenim Türü ve Üniversitelerine Göre İncelenmesi. Mersin Üniversitesi Eğitim Fakültesi Dergisi, 2(1), 98-110.

Aşkar, P. ve Umay, A. (2001). İlköğretim matematik öğretmenliği öğrencilerinin bilgisayarla ilgili özyeterlik algısı, Hacettepe Üniversitesi Eğitim Fakültesi Dergisi, 21, 1-8.

Aydın, F. ve Coşkun, M. (2011). Geography teacher candidates' metacognitive awareness levels: A case study from turkey. Archives of Applied Science Research, 3 (2):551-557.

Aydın, S. ve Boz, Y. (2010). Pre-service elementary science teachers' science teaching efficacy beliefs and their sources. Elementary Education Online, 9(2), 694-704, 2010.

Bandura A.(1995). Self-efficacy in changing societies. New York, Cambridge University Press.

Bandura, A. (1997). Self efficacy: exercises of control. New York, Freeman.

Baykara, K. (2011). Öğretmen adaylarının bilişötesi öğrenme stratejileri ile öğretmen yeterlik algıları üzerine bir çalışma, Hacettepe Üniversitesi Eğitim Fakültesi Dergisi, 40, 80-92.

Can, B, Günhan-Cantürk, B, Erdal, Ö., S. (2005). Fen bilgisi öğretmen adaylarının fen derslerinde matematiğin kullanımına yönelik özyeterlik inançlarının incelenmesi, Pamukkale Üniversitesi Eğitim Fakültesi Dergisi, 47-54, 17.

Candan, A. (2005). Üstbilişsel kuram ve tarih öğretimi. Kastamonu Eğitim Dergisi, 13, 2, 327-332.

Clause, C. S., Delbridge, K., Schmitt, N., Chan, D., and Jennings, D. (2001). Test preparation activities and employment test performance. Human Performance, 14(2), 149-167.

Çakıroğlu, A. (2007). Üstbilişsel strateji kullanımının okuduğunu anlama düzeyi düşük öğrencilerde erişi artırımına etkisi. Yayımlanmamış doktora tezi, Gazi Üniversitesi, Ankara.

Çubukçu, Z. ve Girmen, P. (2007). "Öğretmen adaylarının sosyal-öz yeterlik algılarının belirlenmesi. Eskişehir Osmangazi Üniversitesi Sosyal Bilimler Dergisi, 8 (1); 57-74.

Çuhadar, C., Gündüz, Ş. ve Tanyeri, T. (2013). Bilgisayar ve öğretim teknolojileri eğitimi bölümü öğrencilerinin ders çalışma yaklaşımları ve akademik öz-yeterlik algıları arasındaki ilişkinin incelenmesi. Mersin Üniversitesi Eğitim Fakültesi Dergisi, 9, 1.

Demir-Gülşen, M. (2000), "A model to Investigate probability and mathematics achievement in terms of cognitive, metacognitive and affective variables", Yüksek Lisans Tezi, Boğaziçi Üniversitesi the Institute for Graduate Studies in Science and Engineering, İstanbul.

Demir, Ö. ve Özmen, S. (2011). Üniversite öğrencilerinin üst biliş düzeylerinin çeşitli değişkenler açısından incelenmesi. Çukurova Üniversitesi Sosyal Bilimler Enstitüsü Dergisi, 20, 3, 145160.

Dilci, T. ve Kaya, S. (2012). 4. ve 5. sınıflarda görev yapan sınıf öğretmenlerinin üstbilişsel farkındalık düzeylerinin çeşitli değişkenler açısından incelenmesi. SDÜ Fen Edebiyat Fakültesi Sosyal Bilimler Dergisi, 27, 247-267.

Doğan, N., Beyaztaş, İ. B. ve Koçak, Z. (2012). Sosyal bilgiler dersine ilişkin özyeterlik düzeyinin başarıya etkisinin sınıf ve cinsiyete göre incelenmesi: Erzurum İli örneği, Eğitim ve Bilim, 37, $165,224-236$.

Doğanay, A. (1997), Ders dinleme sırasında bilişsel farkındalıkla ilgili stratejilerin kullanımı, Çukurova Üniversitesi Eğitim Fakültesi Dergisi, 2, 15, 34-42. 
Durdukoca, Ş. F. (2010). Sınıf öğretmeni adaylarının akademik öz yeterlik algılarının çeşitli değişkenler açısından incelenmesi. Abant İzzet Baysal Üniversitesi Dergisi, 10(1), 69-77.

Eccles, J. and Wigfield, A. (2002). Motivational beliefs, values and goals. Annual Review of Psychology, 53,109-132.

Ekici, G. (2005). Biyoloji Özyeterlik Ölçeğinin Geçerlik ve Güvenirliği. Hacettepe Üniversitesi Eğitim Fakültesi Dergisi, 29, 85-94.

Ekici, G. (2008). Teknik öğretmenlerin ve teknik öğretmen adaylarının teknolojiye yönelik tutumlarının karşılaştıııması. Gaziosmanpaşa Üniversitesi Sosyal Bilimler Araştırmaları Dergisi, 3 (1), 4255.

Flavell, J. H. (1979). Metacognition and cognitive monitoring: A new area of cognitive-developmental inquiry. American Psychologist, 34, 906-911.

Gelen, İ. (6-9 Temmuz 2004). Bilişsel farkındalık stratejilerinin türkçe dersine ilişkin tutum, okuduğunu anlama ve kalıclığa etkisi. XIII. Ulusal Eğitim Bilimleri Kurultayı, İnönü Üniversitesi, Eğitim Fakültesi, Malatya.

Hismanoğlu, M. (2000). Language learning strategies in foreign language learning and teaching. The Internet TESL, VI, 8.

Hazır-Bıkmaz, F. (2004). Sınıf öğretmenlerinin fen öğretiminde öz-yeterlilik inancı ölçeğinin geçerlik ve güvenirlik çalışması. Milli Eğitim Dergisi, 161.

Howard, B. C., McGee, S., Shia, R. and Namsoo, H. (24-28 April, 2000). Metacognitive self-regulation and problem-solving: expanding the theory base through factor analysis. American Educational Research Association, New Orleans.

Küçük-Özcan, Z. Ç. (2000). Teaching metacognitive strategies to 6th grade students. Unpublished B.S. Thesis. İstanbul: Bogaziçi University, the Institute of Science and Engineering.

Landline J, Stewart J. (1998). Relationship between metacognition, motivation, locus of control, selfefficacy and academicachievement. Canadian Journal of Counseling, 32(3), 200-212

Lindsay-Coleen, P. (2010). Assessing the Relationshıps among Goal Orientation, Test Anxiety, SelfEfficacy, Metacognition, and Academic Performance. Unpublished B.S. Thesis, Northern Illınois University.

Memnun, D.S. ve Akkaya, R. (2009). The levels of metacognitive awareness of primary teacher trainees. Procedia Social and Behavioral Sciences, 1, 1919-1923.

Namlu, A. (2004). Bilişötesi öğrenme stratejilerinin ölçme aracının geliştirilmesi. Anadolu Üniversitesi Sosyal Bilim/er Dergisi, 2, 123-136.

Oğuz, A. (2012). Sınıf Öğretmeni Adaylarının Akademik Öz Yeterlik İnançları. Anadolu Journal of Educational Sciences International, July, 2(2), 15-28.

Özsoy, G. (2008). Üstbiliş. Türk Eğitim Bilimleri Dergisi, 6(4), 713-740.

Özsoy, G., Çakıroğlu, A. ve Kuruyer, G. H. (20-22 Mayıs 2010). Sınıf öğretmeni adaylarının üstbilişsel farkındalık düzeylerinin bazı değişkenler bakımından incelenmesi. 9. Sınıf Öğretmenliği Egitimi Sempozyumu, 489-492. 2010.

Özsoy, G. ve Günindi, Y. (2011). Okulöncesi öğretmen adaylarının üstbilişsel farkındalık düzeyleri. İlkögretim Online Dergisi, 10, 2, 430-440.

Özsüer, S., İnal, G., Uyanık, Ö. ve Ergün, M. (2011). Afyon Kocatepe Üniversitesinde öğrenim gören öğrencilerin akademik özyeterlik inanç düzeylerinin incelenmesi. Afyon Kocatepe Üniversitesi Sosyal Bilimler Dergisi, 13, 2.

Pajares, F. (1996). Self-Efficacy Beliefs in Academic Settings. Review of Educational Research, 66, 543-578.

Saracaloğlu A.S., Karasakaloğlu N., Gencel I.E. (2010). Türkçe öğretmenlerinin özyeterlik düzeylerinin çeşitli değişkenlere göre incelenmesi. Elektronik Sosyal Bilimler Dergisi, 9,33, 265-283. 
Schoeffler, A. (2012). Using Training in metacognitive skills to enhance constructivist science learning. Unpublished B.S Thesis. Montana: Montana State University.

Schunk, D. and Pajares, F. (2001). The Development of Academic Self-Efficacy. A. Wigfield and J. Eccles (Eds.), Development of achievement motivation. San Diego: Academic Press.

Üredi, I. ve Üredi, L. (2005). Sınıf öğretmeni adaylarının cinsiyetlerine, bulundukları sınıflara ve başarı düzeylerine göre fen öğretimine ilişkin öz-yeterlik inançlarının karşılaştırılması. Mersin Üniversitesi Eğitim Fakültesi Dergisi, 1, 2, 250-260.

Üstün, A. ve S. Tekin, "Amasya Eğitim Fakültesi Öğretmen Adaylarının Öz Yeterlilik İnançlarının Çeşitli Değişkenler Açısından Karşıllaştıııması", Bolu Abant İzzet Baysal Üniversitesi Eğitim Fakültesi Dergisi, 9, 1, 35-47.

Yasa, S. ve Şahin, M. (2012). Resim iş eğitimi öğrencilerinin öğretmenlik mesleğine yönelik öz-yeterlik algıları ve yaratıcılık düzeyleri. Akdeniz Eğitim Araştırmaları Dergisi, 11, 67-76.

Yılmaz, M., Gürçay, D. ve Ekici, G. (2007) Akademik özyeterlik ölçeğinin Türkçe'ye uyarlanması. Hacettepe Üniversitesi Egitim Fakültesi Dergisi, 33, 253-259.

\section{EXTENDED ABSTRACT}

For individuals to adapt to the 21st century information age, they should have such qualifications as problem-solving, critical thinking, research making, using knowledge creatively and producing knowledge and technology. To have these qualifications, they should have knowledge about their own cognitive systems; that is, they should be able to use their meta-cognitive strategies. Studies show that meta-cognitive learning skills develop the thinking skills, increase the learning speed and level, develop problem solving skills, give self-confidence, increase motivation and attitudes, improve reading comprehension skills, increase planning and self-evaluation skills, enable independent learning, increase academic success and develop critical-creative and reflective thinking skills. Perceived academic self-efficacy is a belief that student's completing an academic task on his/her own successfully. Academic self-efficacy belief is, on the other hand, an important process in stimulating individuals in planning and realizing their aims. Teachers have great responsibility in having students with these qualifications. For this reason, it is important to identify teachers' beliefs about their metacognitive strategies and academic self-efficacy, also to examine the relationship between these concepts in order to train individuals according to fundemental aims of education. In this context the purpose of this study is to determine whether there is a relationship between the pre-service teachers' metacognitive learning strategies and academic self-efficacy. Moreover, the study also looks at whether the metacognitive learning strategies and academic self-efficacy varies depending on the variables such as gender, the classroom level, achievement and university. The study group of this research employing a survey model consists of 794 pre-service teachers of all the departments of the Education Faculty of Ankara University, Anadolu University and Osmangazi University. In data collection procedure two instrument is used. First one is "Academic Self-Efficacy Beliefs Scale" which was developed by Jerusalem ve Schwarzer (1981) and validity and reliability studies were done for Turkish population by Yllmaz, Gürçay and Ekici (2007) and second one is "Meta-Cognitive Strategies Scale" which was developed and also validity and reliability studies carried out by Namlu (2004). Pearson Moments Product Correlation Coefficient, $\mathrm{t}$ test, ANOVA and Kruskall Wallis $\mathrm{H}$ test were used in the analysis of the data. The findings of the study revealed that there are significant relations between the sub-dimensions of the metacognitive learning strategies and academic self-efficacy; preservice teacher's metacognitive learning strategies differ significantly in terms of gender, achievement and university; academic self-efficacy differ significantly in terms of the classroom level, achievement and university. 